\title{
Growth and Instability of Pulses Production in Andhra Pradesh
}

\author{
N.S. Praveen Kumar ${ }^{1 *}$, Y. Radha ${ }^{1}$, D.V. Subba Rao ${ }^{1}$, \\ V. Srinivasa Rao ${ }^{2}$ and T. Gopikrishna ${ }^{3}$ \\ ${ }^{1}$ Department of Agricultural Economics, Agricultural College, Bapatla, AP, India \\ ${ }^{2}$ Department of Statistics \& Computer Applications, Agricultural College, Bapatla, AP, India \\ ${ }^{3}$ Department of Agricultural Extension, ANGRAU, Guntur, AP, India \\ *Corresponding author
}

A B S T R A C T

\section{Ke y w ords \\ Pulses, Growth rate, instability index, \\ Decomposition analysis \\ Article Info \\ Accepted: \\ 07 October 2018 \\ Available Online: \\ 10 November 2018}

\begin{abstract}
This paper analyses the growth rates and instability indices of major pulses in Andhra Pradesh. Decomposition analysis was carried out to measure the relative contribution of area and yield to the growth in total production of major pulses. The study period has been divided into two sub periods for the purpose of analysis of growth rates and decomposition analysis viz., 1995-96 to 2005-2006 and 2005-06 to 2015-16. Growth rate analysis showed that both the production and yield of major pulse crops were positive whereas the area was positive except for green gram and black gram. The instability indices indicate that during the periods I and II, instability in area, production and yield was high in red gram expect for yield in period I which was highest in bengal gram.
\end{abstract}

\section{Introduction}

Pulses are an integral part of many diets across the globe and they have great potential to improve human health, conserve our soils, protect the environment and contribute to global food security. The United Nations, declared 2016 as "International Year of Pulses" (IYP) to heighten public awareness of the nutritional benefits of pulses as part of sustainable food production aimed at food security and nutrition. India is the largest producer $(25 \%$ of global production), consumer ( $27 \%$ of world consumption) and importer (14\% of world imports) of pulses in the world. Pulses account for around 20 per cent of the area under food grains and contribute around 7 per cent to 10 per cent of the total food grains production in the country. Though pulses are grown in both kharif and rabi seasons, rabi pulses contribute more than 60 per cent of the total production (Smita Mohanty and Satyasai, 2015). Climate change will surely have an adverse effect on productivity of pulses on account of reduction in total crop cycle duration.

Therefore, an analysis of growth and instability in pulses production in Andhra Pradesh is of great importance for a comprehensive understanding of the food security at the state level. In this context the present paper analyses growth and instability of major pulses crops in Andhra Pradesh. 


\section{Materials and Methods}

The study pertains to Andhra Pradesh state Secondary data for the period 1995-96 to 2015-16 on area, production and productivity were collected from various issues of Statistical Abstracts published by the Bureau of Economics and Statistics, Government of Andhra Pradesh

Compound growth rates were estimated by fitting an exponential function of the following form for the periods 1995-96 to 2005-06 and 2006-07-2015-16.

$\mathrm{Y}=\mathrm{A} \cdot \mathrm{b}^{\mathrm{t}}$

$\log Y=\log A+t . \log b$

Where,

$\mathrm{Y}=$ Area/production/productivity

$\mathrm{A}=$ Constant $\mathrm{b}=(1+\mathrm{r})$

$\mathrm{r}=$ Compound Growth Rate

$\mathrm{t}=$ Time variable in years $(1,2,3 \ldots \mathrm{n})$

The value of antilog of ' $b$ ' was estimated by using LOGEST function in MS-Excel.

Then, the Compound Growth Rate is calculated as below;

$\operatorname{CGR}(\%)=\left[\operatorname{LOGEST}\left(\mathrm{Y}_{1}: \mathrm{Y}_{10}\right)-1\right] \times 100$

The instability indices of area, production and yield were estimated using Coppock's Instability Index (CII) for the two periods 1995-96 to 2005-06 and 2006-07-2015-16. CII can be estimated by using the formula:

$\mathrm{V}={ }^{\frac{1}{N}}\left[\log +\frac{x_{t+1}}{x t}-\mathrm{m}\right]^{2}$

The instability index $=[($ Antilog of $\sqrt{V-1})] \mathrm{x}$ 100

Where,
$\mathrm{X}_{\mathrm{t}}=$ Variable (area/production/yield) in year $\mathrm{t}$

$\mathrm{X}_{\mathrm{t}+1}=$ variable in $\mathrm{t}+1$ year

$\mathrm{t}=1$ to $\mathrm{n}$ no. of years,

$\mathrm{N}=\mathrm{n}-1$

$\mathrm{m}=\frac{1}{N} \sum_{t=1}^{n-1}\left(\ln X_{t+1}-\ln X_{t}\right)$

Decomposition of change in production will result into area effect, yield effect and interaction effect of area and yield, which can be represented as

$\Delta \mathrm{P}=\mathrm{A}_{\mathrm{o}} * \Delta \mathrm{Y}+\mathrm{Y}_{\mathrm{o}} * \Delta \mathrm{A}+\Delta \mathrm{A} * \Delta \mathrm{Y}$

Where,

$\Delta \mathrm{P}=$ Production difference

$\mathrm{Y}_{\mathrm{o}} * \Delta \mathrm{A}=$ Area effect

$\mathrm{A}_{0} * \Delta \mathrm{Y}=$ yield effect

$\Delta \mathrm{A}^{*} \Delta \mathrm{Y}=$ Interaction effect of area and yield.

\section{Results and Discussion}

Growth rate analysis of area, production and yield of major pulse crops

The estimated Compound Growth Rates (CGR) in area, production and yield of major pulse crops in Andhra Pradesh are presented in Table 1. For three periods, viz., 1996-2005, 2006-2015 and 1966-2015.

The growth rates of area, production and yield were positive for red gram and bengal gram where as they were negative for green gram and black gram during period I. In period II, the growth rates of area, production and yield were positive for red gram, green gram and black gram where as it was negative for bengal gram.

In the overall period (1996-2015), production and yield of red gram, bengal gram, black gram and green gram were positive, while the area of red gram and bengal gram were positive whereas for green gram and black gram it was negative which may be due 
increased incidence of the diseases like pulse crops grown in Andhra Pradesh are Yellow Vein Mosaic Virus. (Reddy et al., presented in the Table 2 and are discussed 2005)

Instability analysis of area, production and yield of major pulse crops

The results of the Coppock's instability analysis of area, production and yield of major crop wise for the two periods including overall period.

The instability analysis showed that, in period I (1996-2005) the highest instability in area was observed in red gram (13.47) and the lowest in bengal gram.

Table.1 Compound Growth Rate for area, production and yield of Major pulse crops in Andhra Pradesh

\begin{tabular}{|c|c|c|c|c|c|}
\hline S. No. & Crop & Particulars & Period I & Period II & Overall Period \\
\hline \multirow[t]{3}{*}{1.} & \multirow[t]{3}{*}{ Red gram } & Area & $7.17 * * *$ & 0.75 & 0.27 \\
\hline & & Production & $9.77 * * *$ & $3.20 * *$ & $1.86^{*}$ \\
\hline & & Yield & $2.44 * * *$ & $2.43 * *$ & 1.58 \\
\hline \multirow[t]{3}{*}{2.} & \multirow{3}{*}{$\begin{array}{l}\text { Bengal } \\
\text { gram }\end{array}$} & Area & $18.94 * * *$ & $-1.97 *$ & $9.56^{* * *}$ \\
\hline & & Production & $27.26 * * *$ & $-3.32 * *$ & $11.84 * * *$ \\
\hline & & Yield & $6.99 * * *$ & -1.37 & $2.09 *$ \\
\hline \multirow[t]{3}{*}{3} & \multirow[t]{3}{*}{ Green gram } & Area & 0.34 & 1.28 & -1.77 \\
\hline & & Production & $-3.09 * *$ & $11.77 * * *$ & 0.77 \\
\hline & & Yield & $-3.42 * * *$ & $10.34 * * *$ & $2.58 * *$ \\
\hline \multirow[t]{3}{*}{4.} & \multirow[t]{3}{*}{ Black gram } & Area & -1.77 & -0.52 & -1.06 \\
\hline & & Production & $-2.17^{*}$ & $4.30 * * *$ & 0.74 \\
\hline & & Yield & -1.02 & $4.84 * * *$ & 1.81 \\
\hline
\end{tabular}

Table.2 Coppock's Instability Indices for area, production and yield of major pulse crops in Andhra Pradesh

\begin{tabular}{|c|c|c|c|c|c|}
\hline S. No. & Crop & Particulars & Period I & Period II & Overall period \\
\hline \multirow{3}{*}{1.} & \multirow[t]{3}{*}{ Redgram } & Area & 13.47 & 13.62 & 13.67 \\
\hline & & Production & 17.50 & 16.91 & 17.79 \\
\hline & & Yield & 15.12 & 14.12 & 14.92 \\
\hline \multirow[t]{3}{*}{2.} & \multirow[t]{3}{*}{ Bengalgram } & Area & 12.16 & 11.97 & 12.43 \\
\hline & & Production & 16.65 & 13.07 & 15.11 \\
\hline & & Yield & 16.68 & 12.10 & 14.95 \\
\hline \multirow[t]{3}{*}{3} & \multirow[t]{3}{*}{ Greengram } & Area & 13.13 & 12.96 & 12.97 \\
\hline & & Production & 17.02 & 13.41 & 15.27 \\
\hline & & Yield & 13.53 & 12.80 & 13.18 \\
\hline \multirow[t]{3}{*}{$\overline{4 .}$} & \multirow[t]{3}{*}{ Blackgram } & Area & 12.27 & 13.07 & 12.67 \\
\hline & & Production & 14.78 & 14.06 & 14.47 \\
\hline & & Yield & 13.06 & 12.81 & 12.91 \\
\hline
\end{tabular}


Table.3 Decomposition analysis of change in production of pulse crops in Andhra Pradesh

\begin{tabular}{|c|c|c|c|c|c|}
\hline S. No. & Crop & Particulars & Period I & Period II & Overall Period \\
\hline \multirow[t]{3}{*}{1.} & \multirow[t]{3}{*}{ Red gram } & Area effect & 46.19 & 47.28 & 50.72 \\
\hline & & Yield effect & 40.22 & 31.15 & 36.86 \\
\hline & & Interaction effect & 13.59 & 21.57 & 12.43 \\
\hline \multirow[t]{3}{*}{2.} & \multirow[t]{3}{*}{ Bengal gram } & Area effect & 10.09 & -116.58 & 1.37 \\
\hline & & Yield effect & 53.94 & 209.71 & 90.83 \\
\hline & & Interaction effect & 35.97 & 6.87 & 7.83 \\
\hline \multirow[t]{3}{*}{3} & \multirow[t]{3}{*}{ Green gram } & Area effect & 59.05 & 61.92 & 76.90 \\
\hline & & Yield effect & 51.78 & 21.65 & 17.82 \\
\hline & & Interaction effect & -10.83 & 16.43 & 5.29 \\
\hline \multirow[t]{3}{*}{4.} & \multirow[t]{3}{*}{ Black gram } & Area effect & 265.53 & 62.09 & 86.98 \\
\hline & & Yield effect & 79.00 & 32.25 & 9.57 \\
\hline & & Interaction effect & -5.53 & 5.66 & 3.45 \\
\hline
\end{tabular}

In case of production the highest instability was recorded in red gram (17.50) and in case of yield the highest instability was observed in bengal gram (16.68). The lowest instability in production (14.78) and yield (13.06) was recorded in black gram. In period II (20062015), the highest instability in area was recorded in red gram (13.62) and the lowest in Bengal gram (11.97). The highest instability in production (16.91) and yield (14.12) was recorded in red gram and the lowest instability in production (13.07) and yield (12.10) was recorded in bengal gram (Rama Rao et al., 2012). In overall period (19962015), the highest instability in area was recorded in red gram (13.67) and lowest instability in bengal gram (12.43). The highest instability in production was recorded in red gram (17.79) whereas for yield it was highest in bengal gram (14.95).The lowest instability in production (14.47) and yield (12.91) was recorded in black gram.

\section{Decomposition analysis}

Total production of crop output is determined mainly by area, yield and the interaction effect of its area and yield, besides several other factors.
The decomposition analysis as specified in Table 3 revealed that, in period I (1996-2005) the contribution of area and yield effects were positive and more responsible for the production of red gram, black gram and green gram. The interaction effect was positive in red gram and bengal gram whereas for green gram and black gram it was negative. In period II (2006-2015), except in bengal gram the area effect was positive in all the crops. In bengal gram, green gram and black gram the yield effect was positive and more responsible for production of these crops.

In overall period (1996-2015), the area effect was found to be positive for all crops and contribution of area and yield effect was responsible for production in red gram. The area effect was more responsible for production in case of black gram and green gram where as in case of bengal gram yield effect was more responsible for the production.

Growth rate analysis showed that both the production and yield of major pulse crops were positive whereas the area was positive except for green gram and black gram. The instability indices indicate that during the 
periods I and II, instability in area production and yield was high in red gram expect for yield in period I which was highest in bengal gram. From the results of the decomposition analysis it is concluded that variation in production of the pulse crops was mainly due to the area effect except in bengal gram crop. In bengal gram the variation in production was mainly due to yield effect.

\section{References}

Rama Rao, I.V.Y., Vasudev, $\mathrm{N}$ and Sunil Kumar Babu G. 2012. Growth in foodgrain production in India is technology led or policy led: Special reference to Andhra Pradesh with district wise economic analysis. Agricultural situation of India November, 409-418.

Reddy, A. Amarender, 2005. Growth and instability in chickpea production in India: A state level analysis, Agricultural Situation in India. Vol. LXII, (9): 621-628.

Smita Mohanty and Satyasai, K.J. 2015. Feeling the pulse. Nabard Rural Pulse. Issue $\mathrm{X}$ - July - august.

\section{How to cite this article:}

Praveen Kumar, N.S., Y. Radha, D. V. Subba Rao, V. Srinivasa Rao and Gopikrishna, T. 2018. Growth and Instability of Pulses Production in Andhra Pradesh. Int.J.Curr.Microbiol.App.Sci. 7(11): 490-494. doi: https://doi.org/10.20546/ijcmas.2018.711.058 